\title{
In silico phylogenetic and virulence gene profile analyses of avian pathogenic Escherichia coli genome sequences ${ }^{1}$
}

\author{
Thaís C.G. Rojas², Renato P. Maluta², Luciano V. Koenigkan³ and Wanderley Dias da Silveira²*
}

\begin{abstract}
Rojas T.C.G., Maluta R.P., Koenigkan L.V. \& Dias da Silveira W. 2014. In silico phylogenetic and virulence gene profile analyses of avian pathogenic Escherichia coli genome sequences. Pesquisa Veterinária Brasileira 34(2):129-133. Departamento de Genética, Evolução e Bioagentes, Instituto de Biologia, Universidade de Campinas, Cx. Postal 6109, Campinas, SP 13083-970, Brazil. E-mail: wds@unicamp.br

Avian pathogenic Escherichia coli (A $\overline{\mathrm{PEC}}$ ) infections are responsible for significant losses in the poultry industry worldwide. A zoonotic risk has been attributed to APEC strains because they present similarities to extraintestinal pathogenic E. coli (ExPEC) associated with illness in humans, mainly urinary tract infections and neonatal meningitis. Here, we present in silico analyses with pathogenic $E$. coli genome sequences, including recently available APEC genomes. The phylogenetic tree, based on multi-locus sequence typing (MLST) of seven housekeeping genes, revealed high diversity in the allelic composition. Nevertheless, despite this diversity, the phylogenetic tree was able to cluster the different pathotypes together. An in silico virulence gene profile was also determined for each of these strains, through the presence or absence of 83 well-known virulence genes/traits described in pathogenic E. coli strains. The MLST phylogeny and the virulence gene profiles demonstrated a certain genetic similarity between Brazilian APEC strains, APEC isolated in the United States, UPEC (uropathogenic E. coli) and diarrheagenic strains isolated from humans. This correlation corroborates and reinforces the zoonotic potential hypothesis proposed to APEC.
\end{abstract}

INDEX TERMS: Avian pathogenic Escherichia coli (APEC), Multi-locus Sequence Typing (MLST), phylogenetic tree, virulence genes.

RESUMO.- [Análises in silico da filogenia e do perfil de genes associados à virulência, dos genomas de linhagens de Escherichia coli de origem aviária.] As infecções causadas por linhagens de Escherichia coli de origem aviária (APEC) são responsáveis por perdas significativas na indústria avícola em todo mundo. Risco zoonótico tem sido atribuído às linhagens APEC, devido às semelhanças existentes entre elas e linhagens de E. coli patogênicas extraintestinais (ExPEC) de origem humana, causadoras de infecções no trato urinário e meningite neonatal. Neste trabalho, apresentamos os resultados de análises in silico feitas a partir dos genomas de linhagens patogênicas de E. coli, incluindo genomas recentemente obtidos de linha-

\footnotetext{
${ }^{1}$ Received on September 27, 2013.

Accepted for publication on January 7, 2014.

${ }^{2}$ Departamento de Genética, Evolução e Bioagentes, Instituto de Biologia, Universidade de Campinas (Unicamp), Cx. Postal 6109, Campinas, SP 13083-970, Brazil. *Corresponding author: wds@unicamp.br

${ }^{3}$ Embrapa Informática Agropecuária, Avenida Dr. André Tosello 209, Barão Geraldo, Cx. Postal 6041, Campinas, SP 13083-886.
}

gens APEC. Uma árvore filogenética foi obtida, com base na tipagem de sequência multilocus (MLST) de sete genes essenciais, revelando alta diversidade na composição de alelos, mas ainda assim possibilitando o agrupamento dos diferentes patótipos. Foi determinado também, para cada linhagem, o perfil gênico, por meio da presença ou ausência de 83 genes associados à virulência. A árvore filogenética e o perfil gênico demonstraram que existem semelhanças genéticas entre cepas APEC brasileiras, APEC isolada nos Estados Unidos, UPEC (uropathogenic E. coli) e linhagens produtoras de diarreia em humanos. Essa correlação corrobora e reforça a hipótese de que linhagens APEC apresentam potencial risco zoonótico.

TERMOS DE INDEXAÇÃO: Escherichia coli de origem aviária (APEC), tipagem de sequência multilocus (MLST), árvore filogenética, genes associados à virulência.

\section{INTRODUCTION}

Escherichia coli associated with extraintestinal diseases (ExPEC), include avian pathogenic E. coli (APEC), neonatal 
meningitis E. coli (NMEC) and uropathogenic E. coli (UPEC) (Dziva \& Stevens 2008). APEC infections are collectively denominated colibacillosis. The infection may be local or systemic, and has been responsible for severe losses in the poultry industry worldwide. Losses are due to carcass condemnation, mortality and decrease in egg production (Dho-Moulin \& Fairbrother 1999, Barnes et al. 2008).

Previous studies demonstrated that APEC, NMEC and UPEC strains share common virulence genes, overlapped 0 serogroups and phylogenetic groups (Rodriguez-Siek et al. 2005, Ewers et al. 2007, Moulin-Schouleur et al. 2007). These characteristics were corroborated by multilocus sequence typing (MLST) and genome comparison data (Johnson et al. 2007, Moulin-Schouleur et al. 2007) and led to a further hypothesis that APEC strains could act as UPEC or NMEC and, therefore, constitute a zoonotic risk. A recent work (Dziva et al. 2013) demonstrated that an APEC strain was more closely related to a human ST23 ETEC (enterotoxigenic E. coli) than to strain APEC 01. This suggests that the core genome of ST23 strains has the potential to generate variants able to cause disease on avian or human, depending of the accessory genome. For urinary tract infections and new-born meningitis, it has been hypothesized that APEC could access and colonize the human colon via the ingestion of contaminated poultry and then reach the urinary tract or the central nervous system (Rodriguez-Siek et al. 2005). Thereby, APEC could act as a cause of human ExPEC infections or as a virulence gene reservoir for human ExPEC strains, thus representing a possible zoonotic risk (Rodriguez-Siek et al. 2005, Moulin-Schouleur et al. 2007).

The availability of APEC genome sequences (Johnson et al. 2007, Rojas et al. 2012, 2013) permits the comparison of genome contents between APEC and human ExPEC strains, and helps to understand the evolutionary processes involved in shaping the phenotypes of different $E$. coli pathotypes. The phylogeny (based on MLST) and the cluster (based on the presence or absence of virulence genes) analyses, may be helpful to highlight the similarities between these different strains, and the potential nonspecific host relationships. In this work, the virulence gene profiles and the phylogenetic relationships of APEC strains were analyzed and compared to other previously published human pathogenic strains, to verify possible genetic similarities and the potential pathogenicity risk for birds and human beings.

\section{MATERIALS AND METHODS}

The MLST tree and the virulence gene profile analysis were performed with 14 pathogenic Escherichia coli genome sequences. The strains and their respective plasmids were chosen because they are representative of the pathotypes herein studied (Table 1).

MLST analysis, conducted in silico, were performed with all the allele sequences of the seven housekeeping genes adk (adenylate kinase), fumC (fumarate hydratase), gyrB (DNA gyrase), icd (isocitrate/isopropylmalate dehydrogenase), $m d h$ (malate dehydrogenase), purA (adenylosuccinate dehydrogenase) and recA (ATP/GTP-binding motif) downloaded from the MLST Databases at the ERI, University College Cork (http://mlst.ucc. $\mathrm{ie} / \mathrm{mlst} / \mathrm{dbs} /$ Ecoli/Downloads_HTML). For each gene, all alleles were searched against the genomes sequences through BLAST tool, on a local platform against a local database, using the softwa-
Table 1. Escherichia coli strains and plasmids analyzed by phylogenetic MLST tree and virulence gene profiles

\begin{tabular}{|c|c|c|c|}
\hline Strain / Plasmid & Pathotype & $\begin{array}{c}\text { e GenBank } \\
\text { accession number }\end{array}$ & Reference \\
\hline $\mathrm{SEPT}_{3}^{3}$ & APEC $^{a}$ & AOGL00000000.1 & 1 (Rojas et al. 2013) \\
\hline S17 & APEC & AOGN00000000.1 & 1 Roja \\
\hline 008 & APEC & AOGM00000000.1 & 1 (Rojas et al. 2013) \\
\hline SCI-07 & APEC & AJFG00000000.1 & (Rojas et al. 2012) \\
\hline APEC & APEC & NC_008563.1 & (Johnson et al. 2007) \\
\hline $\begin{array}{l}\text { pAPEC-01- } \\
\text { ColBM (plasmid) }\end{array}$ & APEC & NC_009837.1 & (Johnson et al. 2006a) \\
\hline blasmid) & APEC & NC_009838.1 & (Johnson et al. 2006b) \\
\hline 0157 & EHEC $^{\mathrm{b}}$ & NC_002655 & $(\mathrm{Pe}$ \\
\hline 0157 & EHEC & NC_002695.1 & (Bergholz et al. 2007) \\
\hline $\begin{array}{l}7 \text { str. Sakai } \\
\text { (plasmid) }\end{array}$ & EHEC & NC_002128.1 & (Makino et al. 1998) \\
\hline $\begin{array}{l}\text { 0157:H7 str. Sakai } \\
\text { p0SAK1 (plasmid) }\end{array}$ & EHEC & NC_002127.1 & (Makino et al. 1998) \\
\hline 042 & $\mathrm{EAEC}^{\mathrm{c}}$ & FN & (Chaudhur \\
\hline 042 pAA (plasmid) & EAEC & $\mathrm{FN}$ & (Chaudhu \\
\hline $\mathrm{H} 10$ & ETEC $^{d}$ & FN & (Crossme \\
\hline p58 (plasmid) & ETEC & 16 & (Crossma \\
\hline 66 (plasmid) & l) ETEC & 417 & (Crossman et al. 2010) \\
\hline p948 (plasmid) & l) ETEC & 418 & (Crossman et al. 2010) \\
\hline H10407 p52 (plasmid) & ETEC & 415 & (Crossman et al. 2010) \\
\hline LF82 & $\mathrm{AIEC}^{\mathrm{e}}$ & CUt & (Miquel et al. 2010) \\
\hline 0127: & EPEC $^{f}$ & & (Iguchi e \\
\hline $\begin{array}{l}\text { 0127:H6 E2348/69 } \\
\text { pE2348-2(plasmid) }\end{array}$ & EPEC & 70 & (Iouchi et \\
\hline $\begin{array}{l}\text { 0127:H6 E2348/69 } \\
\text { pMAR2 (plasmid) }\end{array}$ & EPEC & FM180569 & IJuchie \\
\hline CFT073 & UPEC $^{g}$ & $\mathrm{AE}$ & (We \\
\hline & UPEC & NC_O & \\
\hline $\begin{array}{l}\text { UTI89 pUTI89 } \\
\text { (plasmid) }\end{array}$ & UPFC & 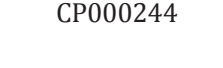 & 1. 2006) \\
\hline S88 & & & \\
\hline pECOS88 (plasmid) & NMEC & CU928146 & (Peigne et al. 2009) \\
\hline
\end{tabular}

${ }^{a}$ Avian pathogenic E. coli (APEC), ${ }^{b}$ Enterohemorragic E. coli (EHEC), ${ }^{c}$ Ente-

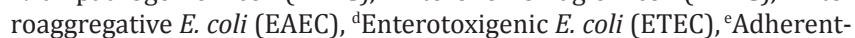
-invasive E. coli (AIEC), ${ }^{\mathrm{f}} \mathrm{E}$ teropathogenic E. coli (EPEC), ${ }^{\mathrm{g}} \mathrm{Uropathoge}-$ nic E. coli (UPEC), ${ }^{\text {h}}$ Neonatal meningitis E. coli (NMEC).

re BLAST 2.2.26 with the application blastn. The allele with the lowest e-value was then considered as the allele present in the strain. For each strain, the sequences of the correspondent alleles, for the seven housekeeping genes, were concatenated. All concatenated sequences were aligned with MUSCLE (Edgar 2004). The phylogenetic tree was constructed by the Maximum Likelihood method using MEGA 5.10.

Comparative analysis of virulence genes for several $E$. coli pathotypes was also performed with BLAST 2.2.26 software with the application tblastn that was executed with default parameters except for the e-value, which was adjusted to 1 . A total of 83 proteins, which are representative of virulence associated genes, were searched against 14 chromosomal genomes and their plasmids sequences when available. The proteins were considered present in a genome when the identity percentage was greater than 90 .

Gene Cluster 3.0 software grouped the genomes according to the presence or absence of all tested genes. A binary matrix was constructed to determine the distance, using Pearson correlation coefficient (centered), and clustering was performed by the single linkage. The distance tree was visualized through Java TreeView 1.1.6r2.

\section{RESULTS}

The in silico phylogenetic analysis conducted for APEC, human-associated ExPEC, and enteric pathogenic E. coli 
strains defined which alleles of the seven housekeeping genes ( $a d k$, fum $C$, gyr $B$, icd, $m d h$, purA and $\operatorname{rec} A$ ) were present in each genome sequence. The seven MLST alleles were concatenated and used to generate a Maximum Likelihood tree (Fig.1).

The presence or absence of 83 well-known virulence genes/traits (Kaper et al. 2004, Johnson et al. 2008b), resulted on a virulence gene profile for each strain (Fig.2). The sequence types (ST) identified in the APEC strains recently sequenced by our research group were: ST117 (strain SEPT362), ST363 (strain SCI-07), ST10 (strain S17) and ST453 (strain 008). To our knowledge, ST453 (strain 008 - from an omphalitis case) was not previously detected in other published APEC strains. In MLST database, ST453 was associated with human pathogenic $E$. coli strains ( $E$. coli 28, U2183, HMMC097 and E25). ST363 (SCI-07 - isolated from a swollen head syndrome case) was detected before in two E. coli strains, a nonpathogenic (KK9/10) isolated from a human, and another pathogenic (IMT5119) isolated from a chicken. ST10 (strain S17 - isolated from a septicemia case) was detected in a large range of sources, such as human pathogenic and non-pathogenic strains, water, soil and animal-isolated strains (eg. camel, pig, bovine and wild rabbit). This ST was also identified in E. coli isola-

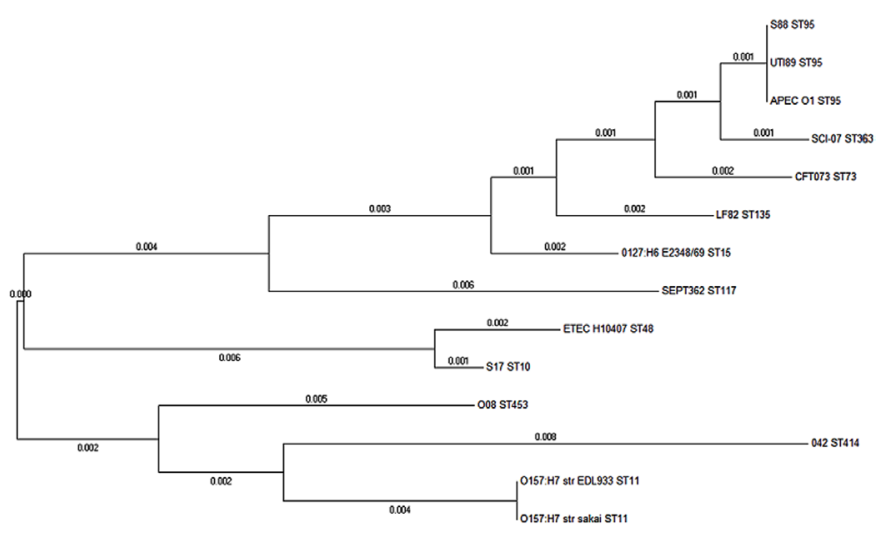

Fig.1. Phylogenetic Maximum Likelihood tree of the concatenated sequences of seven housekeeping genes. The sequence type (ST) is described beside the strain name. ted from birds, such as chicken, wild pigeon and parrot. All strains isolated from wild pigeon and parrot were pathogenic, while there were both pathogenic and nonpathogenic strains isolated from chickens (MLST database). The ST117 (SEPT362 - septicemic) is frequently found in APEC strains, in fact, this ST was the most prevalent type detected in two different studies that determined ST for E. coli isolates from several Danish broiler breeders and layer farms (Gregersen et al. 2010, Olsen et al. 2011) and in the MLST database. This ST is also associated to human urinary tract infections (UTI) (Wu et al. 2012).

In the MLST tree (Fig.1), strain 008 (ST453), together with 042 (enteroaggregative E. coli - EAEC), 0157:H7 str. EDL933 and 0157:H7 str. Sakai (both enterohemorragic E. coli - EHEC), formed a clade that is a sister group to the clade composed by all the other strains. On the other hand, strain APEC SCI-07 (ST363) presented a closer proximity to ST95 human ExPEC strains and APEC 01 (ST95). According to the phylogenetic tree, APEC S17 (ST10) presented a closer similarity to the H10407 ETEC strain (ST48). Strain SEPT362 (ST117) is represented in the phylogenetic tree as an isolated branch, which is a sister clade of that one that includes all human ExPEC strains, AIEC (adherent-invasive E. coli), EPEC (enteropathogenic E. coli) and APEC strains SCI-07 and APEC 01. These results demonstrate that strains isolated from different infectious processes, with a few exceptions, do not present $100 \%$ of identity. However, they could share genomic similarities in the seven housekeeping allelic compositions.

The cluster obtained by the virulence gene profiles (Fig.2) presented slight differences when compared to the MLST phylogenetic tree. Cluster was able to group the strains into two main classes: one composed only of intimin producing enteric strains (0157:H7 str. EDL933; 0157:H7 str. Sakai and 0127:H6 E2348/69) and other composed of all APEC (APEC 01, SCI-07, SEPT362, S17 and 008), human ExPEC (UTI89, S88 and CFT073) and some enteric strains (ETEC H10407, EAEC 042 and AIEC LF82). In this second group, an ExPEC cluster formed by UTI89, S88, APEC 01 and CFT073 was well marked. A clearly defined similarity between strains S17 and ETEC H10407 and between SEPT362, SCI-07 and 008 was noticed, indicating a closer genetic identity, considering the genes herein analyzed.

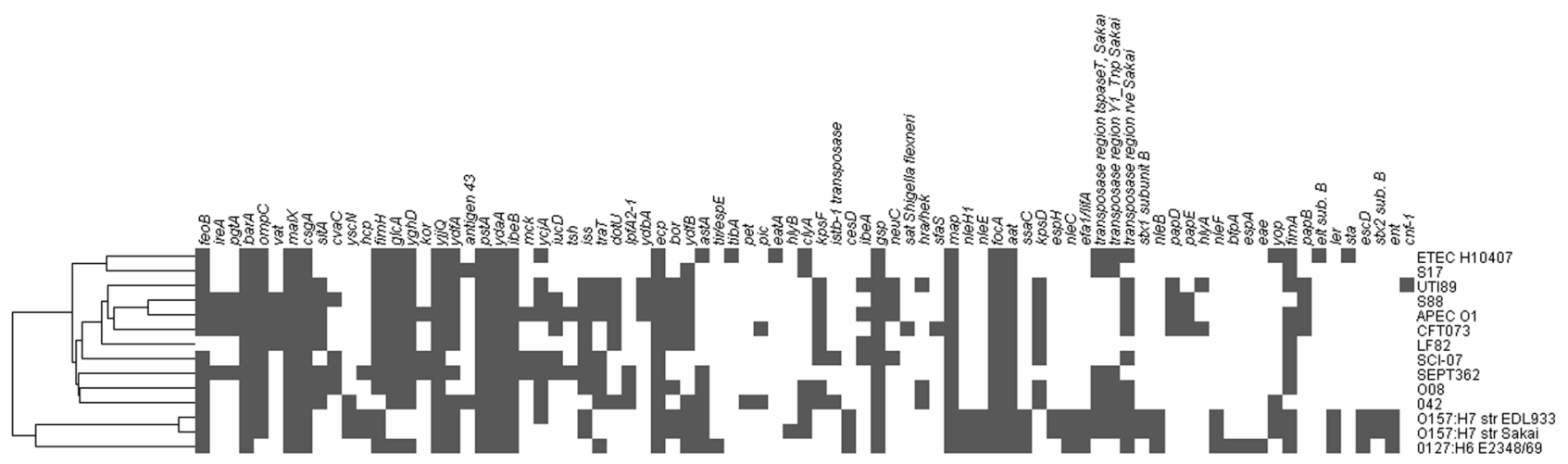

Fig.2. Gene cluster result for 14 pathogenic Escherichia coli strains. The presence (Gray Square) and the absence (White Square) of 83 virulence genes/traits are represented in the image. E. coli strains names are listed on the right. Gene names are listed above the image. 


\section{DISCUSSION}

Several studies aimed to obtain virulence gene profiles in order to define the APEC pathotype. Most of these studies used multiplex PCR and focused on virulence genes localized mainly on the colicin V plasmid (Skyberg et al. 2003, Ewers et al. 2005, Johnson et al. 2008a, Schouler et al. 2012). However, the high diversity encountered in E. coli species difficult the use of a single set of virulence factors for diagnosis (Schouler et al. 2012). For Brazilian APEC strains, a recent study of our group, showed that the analysis of several biological characteristics, such as adhesion to eukaryotic cell cultures, pathogenicity levels according to the lethal dose (50\%) assay, phylogenetic groups and virulence gene profiles, indicated that APEC strains could be organized into a structured set of subgroups associated with specific infectious syndromes (Maturana et al. 2011). These finds demonstrated that APEC strains are very diverse and that the detection of specific genes is not sufficient to define this group. Thus, a study involving MLST (Fig.1) and analysis of a large set of virulence genes, including those found in human ExPEC and enteric strains (Fig.2) were used to group the strains herein studied.

The phylogenetic tree, based on the seven housekeeping genes analyzed (Fig.1), demonstrated that, although the different $E$. coli pathotypes share some genomic similarities, they are very diverse. In addition, these results show that some strains from different origins have either identical or similar housekeeping genes background, notwithstanding their hosts. The virulence gene profiles (Fig.2), presented a higher discriminatory power to differentiate the different $E$. coli pathotypes than the phylogenetic tree, suggesting that gene content appears to be more important in identifying a determined pathotype than the evolutionary history. The phylogenetic analysis, also demonstrated, as indicated by the MLST study, that APEC strains are not a homogeneous group. Thus, the phylogenetic tree and virulence gene profiles revealed that the strains are very diverse, corroborating previous works (Maturana et al. 2011, Schouler et al. 2012). For strain S17, a septicaemic Brazilian APEC, both methodologies clearly showed that it has a closer genetic similarity with strain H10407, a human ETEC strain. In addition, Brazilian strains SEPT362 and SCI-07 shares genetic similarities with human UPEC strains and a previously published APEC strain, APEC 01.

The virulence gene content analysis (Fig.2) displayed a clear discrimination between enteric and ExPEC strains. For ExPEC strains, several virulence factors were widespread (ireA, $c v a C$, iucD, iss, traT, $\operatorname{dot} U$ and neuC), and three genes could be found only in APEC strains (kor, mck and tsh). Human ExPEC strains and APEC 01 were clustered together considering both analyses, but these results were expected since it is known that APEC 01 is indeed similar to UPEC strains (Johnson et al. 2007). Moreover, genes present only in enteric strains (yscN, cesD, nleH1, nleE, ssaC, nleC, efa1/lifA, nleB, nleF, yop, ler, escD and ent) may have contributed to the formation of this ExPEC cluster.

The results demonstrated that APEC strains, with a closer genetic identity to human ExPEC strains, would represent potential zoonotic risks. Moreover, these data suggest the importance of core genomes and virulence genes analyses. These virulence genes are frequently present in plasmids, in Pathogenic islands (PAIs) and other mobile genetic elements. They are freely spread among bacterial genomes, such a way that, specific genes can be preserved or not on strains, depending on the challenges they face. These challenges include colonizing their different hosts, which may also share similar receptors for the bacterial genes products. In this way, evolution would work on two different directions: (1) favoring host-specific strains that could be eradicated in case of a host change and (2) selecting host unspecific strains, which would constitute reservoirs for important virulence genes that would be preserved in the environment. These last strains would have the potential to represent zoonotic risks.

Acknowledgements.- To FAPESP [Proc.2010/51421-8 and 2012/049316] and CAPES [Proc.23038.042588/2008-11]. CNPq provided a fellowship to the main author and to the corresponding author, and FAPESP provided a fellowship to R.P.M. [Proc.2012/05073-3].

\section{REFERENCES}

Barnes H., Nolan L. \& Vaillancourt J. 2008. Colibacillosis, p.691-732. In: Saif Y. (Ed.), Diseases of Poultry. $12^{\text {th }}$ ed. Blackwell Publishing, Ames. 1409p.

Bergholz T.M., Wick L.M., Qi W., Riordan J.T., Ouellette L.M. \& Whittam T.S. 2007. Global transcriptional response of Escherichia coli 0157:H7 to growth transitions in glucose minimal medium. BMC Microbiol. 7:97.

Chaudhuri R.R., Sebaihia M., Hobman J.L., Webber M.A., Leyton D.L., Goldberg M.D., Cunningham A.F., Scott-Tucker A., Ferguson P.R., Thomas C.M., Frankel G., Tang C.M., Dudley E.G., Roberts I.S., Rasko D.A., Pallen M.J., Parkhill J., Nataro J.P., Thomson N.R. \& Henderson I.R. 2010. Complete genome sequence and comparative metabolic profiling of the prototypical enteroaggregative Escherichia coli strain 042. PLoS One 5:e8801.

Chen S.L., Hung C.S., Xu J., Reigstad C.S., Magrini V., Sabo A., Blasiar D., Bieri T., Meyer R.R., Ozersky P., Armstrong J.R., Fulton R.S., Latreille J.P., Spieth J., Hooton T.M., Mardis E.R., Hultgren S.J. \& Gordon J.I. 2006. Identification of genes subject to positive selection in uropathogenic strains of Escherichia coli: a comparative genomics approach. Proc. Natl Acad. Sci. USA 103:5977-5982.

Crossman L.C., Chaudhuri R.R., Beatson S.A., Wells T.J., Desvaux M., Cunningham A.F., Petty N.K., Mahon V., Brinkley C., Hobman J.L., Savarino S.J., Turner S.M., Pallen M.J., Penn C.W., Parkhill J., Turner A.K., Johnson T.J., Thomson N.R., Smith S.G. \& Henderson I.R. 2010. A commensal gone bad: complete genome sequence of the prototypical enterotoxigenic Escherichia coli strain H10407. J. Bacteriol. 192:5822-5831.

Dho-Moulin M. \& Fairbrother J.M. 1999. Avian pathogenic Escherichia coli (APEC). Vet. Res. 30:299-316.

Dziva F., Hauser H., Connor T.R., Van Diemen P.M., Prescott G., Langridge G.C., Eckert S., Chaudhuri R.R., Ewers C., Mellata M., Mukhopadhyay S., Curtiss R., Dougan G., Wieler L.H., Thomson N.R., Pickard D.J. \& Stevens M.P. 2013. Sequencing and functional annotation of avian pathogenic Escherichia coli serogroup 078 strains reveal the evolution of E. coli lineages pathogenic for poultry via distinct mechanisms. Infect. Immun. 81:838-849.

Dziva F. \& Stevens M. 2008. Colibacillosis in poultry: unravelling the molecular basis of virulence of avian pathogenic Escherichia coli in their natural hosts. Avian Pathol. 37:355-366.

Edgar R.C. 2004. Muscle: a multiple sequence alignment method with reduced time and space complexity. BMC Bioinformatics 5:113.

Ewers C., Janssen T., Kiessling S., Philipp H.C. \& Wieler L.H. 2005. Rapid detection of virulence-associated genes in avian pathogenic Escherichia coli by multiplex polymerase chain reaction. Avian Dis. 49:269-273.

Ewers C., Li G., Wilking H., Kieling S., Alt K., Antão E.M., Laturnus C., Diehl 
I., Glodde S., Homeier T., Böhnke U., Steinrück H., Philipp H.C. \& Wieler L.H. 2007. Avian pathogenic, uropathogenic, and newborn meningitis-causing Escherichia coli: How closely related are they? Int. J. Med. Microbiol. 297:163-176.

Gregersen R.H., Christensen H., Ewers C. \& Bisgaard M. 2010. Impact of Escherichia coli vaccine on parent stock mortality, first week mortality of broilers and population diversity of $E$. coli in vaccinated flocks. Avian Pathol. 39:287-295.

Iguchi A., Thomson N.R., Ogura Y., Saunders D., Ooka T., Henderson I.R., Harris D., Asadulghani M., Kurokawa K., Dean P., Kenny B., Quail M.A., Thurston S., Dougan G., Hayashi T., Parkhill J. \& Frankel G. 2009. Complete genome sequence and comparative genome analysis of enteropathogenic Escherichia coli 0127:H6 strain E2348/69. J. Bacteriol. 191:347354.

Johnson T., Johnson S.J. \& Nolan L.K. 2006a. Complete DNA sequence of a ColBM plasmid from avian pathogenic Escherichia coli suggests that it evolved from closely related ColV virulence plasmids. J. Bacteriol. 188:5975-5983.

Johnson T.J., Wannemeuhler Y.M., Scaccianoce J.A., Johnson S.J. \& Nolan L.K. 2006b. Complete DNA sequence, comparative genomics, and prevalence of an IncHI2 plasmid occurring among extraintestinal pathogenic Escherichia coli isolates. Antimicrob. Agents Chemother. 50:3929-3933.

Johnson T.J., Kariyawasam S., Wannemuehler Y., Mangiamele P., Johnson S.J., Doetkott C., Skyberg J.A., Lynne A.M., Johnson J.R. \& Nolan L.K. 2007. The genome sequence of avian pathogenic Escherichia coli strain 01:K1:H7 shares strong similarities with human extraintestinal pathogenic E. coli genomes. J. Bacteriol. 189:3228-3236.

Johnson T.J., Wannemuehler Y., Doetkott C., Johnson S.J., Rosenberger S.C. \& Nolan L.K. 2008a. Identification of minimal predictors of avian pathogenic Escherichia coli virulence for use as a rapid diagnostic tool. J. Clin. Microbiol. 46:3987-3996.

Johnson T.J., Wannemuehler Y., Johnson S.J., Stell A.L., Doetkott C., Johnson J.R., Kim K.S., Spanjaard L. \& Nolan L.K. 2008b. Comparison of extraintestinal pathogenic Escherichia coli strains from human and avian sources reveals a mixed subset representing potential zoonotic pathogens. Appl. Environ. Microbiol. 74:7043-7050.

Kaper J.B., Nataro J.P. \& Mobley H.L.T. 2004. Pathogenic Escherichia coli. Natl Rev. Microbiol. 2:123-140.

Makino K., Ishii K., Yasunaga T., Hattori M., Yokoyama K., Yutsudo C.H., Kubota Y., Yamaichi Y., Iida T., Yamamoto K., Honda T., Han C.G., Ohtsubo E., Kasamatsu M., Hayashi T., Kuhara S. \& Shinagawa H. 1998. Complete nucleotide sequences of $93-\mathrm{kb}$ and $3.3-\mathrm{kb}$ plasmids of an enterohemorrhagic Escherichia coli 0157:H7 derived from Sakai outbreak. DNA Res. 5:1-9.

Maturana V.G., Pace F., Carlos C., Mistretta Pires M., Campos T.A., Nakazato G., Guedes Stheling E., Logue C.M., Nolan L.K. \& Dias da Silveira W. 2011. Subpathotypes of avian pathogenic Escherichia coli (APEC) exist as defined by their syndromes and virulence traits. Open Microbiol. J. 5:55-64.

Miquel S., Peyretaillade E., Claret L., Vallée A., Dossat C., Vacherie B., Zineb E.H., Segurens B., Barbe V., Sauvanet P., Neut C., Colombel J.F., Medigue C.,
Mojica F.J., Peyret P., Bonnet R. \& Darfeuille-Michaud A. 2010. Complete genome sequence of Crohn's disease-associated adherent-invasive $E$. coli strain LF82. PLoS One 5:e12714.

Moulin-Schouleur M., Répérant M., Laurent S., Brée A., Mignon-Grasteau S., Germon P., Rasschaert D. \& Schouler C. 2007. Extraintestinal pathogenic Escherichia coli strains of avian and human origin: link between phylogenetic relationships and common virulence patterns. J. Clin. Microbiol. 45:3366-3376.

Olsen R.H., Stockholm N.M., Permin A., Christensen J.P., Christensen H. \& Bisgaard M. 2011. Multi-locus sequence typing and plasmid profile characterization of avian pathogenic Escherichia coli associated with increased mortality in free-range layer flocks. Avian Pathol. 40:437-444.

Peigne C., Bidet P., Mahjoub-Messai F., Plainvert C., Barbe V., Médigue C., Frapy E., Nassif X., Denamur E., Bingen E. \& Bonacorsi S. 2009. The plasmid of Escherichia coli strain S88 (045:K1:H7) that causes neonatal meningitis is closely related to avian pathogenic $E$. coli plasmids and is associated with high-level bacteremia in a neonatal rat meningitis model. Infect. Immun. 77:2272-2284.

Perna N.T., Plunkett G., Burland V., Mau B., Glasner J.D., Rose D.J., Mayhew G.F., Evans P.S., Gregor J. \& Kirkpatrick H.A. 2001. Genome sequence of enterohaemorrhagic Escherichia coli 0157:H7. Nature 409:529-533.

Rodriguez-Siek K.E., Giddings C.W., Doetkott C., Johnson T.J., Fakhr M.K. \& Nolan L.K. 2005. Comparison of Escherichia coli isolates implicated in human urinary tract infection and avian colibacillosis. Microbiol. 151:2097-2110.

Rojas T.C.G., Maluta R.P., Parizzi L.P., Koenigkan L.V., Yang J., Yu J., Pereira G.A. \& Dias da Silveira W. 2013. Genome sequences of avian pathogenic Escherichia coli strains isolated from Brazilian commercial poultry. Genome Announc. 1:e0011013.

Rojas T.C.G., Parizzi L.P., Tiba M.R., Chen L., Pereira G.A., Sangal V., Yang J., Yu J. \& Dias da Silveira W. 2012. Draft genome of a Brazilian avian-pathogenic Escherichia coli strain and in silico characterization of virulence-related genes. J. Bacteriol. 194:3023.

Schouler C., Schaeffer B., Brée A., Mora A., Dahbi G., Biet F., Oswald E., Mainil J., Blanco J. \& Moulin-Schouleur M. 2012. Diagnostic strategy for identifying avian pathogenic Escherichia coli based on four patterns of virulence genes. J. Clin. Microbiol. 50:1673-1678.

Skyberg J.A., Horne S.M., Giddings C.W., Wooley R.E., Gibbs P.S. \& Nolan L.K. 2003. Characterizing avian Escherichia coli isolates with multiplex polymerase chain reaction. Avian Dis. 47:1441-1447.

Welch R.A., Burland V., Plunkett G., Redford P., Roesch P., Rasko D., Buckles E.L., Liou S.R., Boutin A., Hackett J., Stroud D., Mayhew G.F., Rose D.J., Zhou S., Schwartz D.C., Perna N.T., Mobley H.L., Donnenberg M.S. \& Blattner F.R. 2002. Extensive mosaic structure revealed by the complete genome sequence of uropathogenic Escherichia coli. Proc. Natl. Acad. Sci. USA 99:17020-17024.

Wu G., Ehricht R., Mafura M., Stokes M., Smith N., Pritchard G.C. \& Woodward M.J. 2012. Escherichia coli isolates from extraintestinal organs of livestock animals harbour diverse virulence genes and belong to multiple genetic lineages. Vet. Microbiol. 160:197-206. 